\title{
Temporally stable genetic structure of heavily exploited Atlantic herring (Clupea harengus) in Swedish waters
}

\author{
LC Larsson ${ }^{1}$, L Laikre ${ }^{1}$, C André ${ }^{2}$, TG Dahlgren ${ }^{3}$ and N Ryman ${ }^{1}$ \\ ${ }^{1}$ Division of Population Genetics, Department of Zoology, Stockholm University, Stockholm, Sweden; ${ }^{2}$ Department of Marine Ecology- \\ Tjärnö, Göteborg University, Strömstad, Sweden and 'Department of Zoology, Göteborg University, Göteborg, Sweden
}

\begin{abstract}
Information on the temporal stability of genetic structures is important to permit detection of changes that can constitute threats to biological resources. Large-scale harvesting operations are known to potentially alter the composition and reduce the variability of populations, and Atlantic herring (Clupea harengus) has a long history of heavy exploitation. In the Baltic Sea and Skagerrak waters, the census population sizes have declined by $35-50 \%$ over the last three decades. We compared the genetic structure of Atlantic herring in these waters sampled at least two different times between 1979 and 2003 by assaying 11 allozyme and nine microsatellite loci. We cannot detect any changes in the amount of
\end{abstract}

genetic variation or spatial structure, and differentiation is weak with overall $F_{\mathrm{ST}}=0.003$ among localities for the older samples and $F_{\mathrm{ST}}=0.002$ for the newer ones. There are indications of temporal allele frequency changes, particularly in one of five sampling localities that is reflected in a relatively small local $N_{\mathrm{e}}$ estimate of c. 400 . The previously identified influence of selection at the microsatellite locus Cpa112 remains stable over the 24-year period studied here. Despite little genetic differentiation, migration among localities appears small enough to permit demographic independence between populations.

Heredity (2010) 104, 40-51; doi:10.1038/hdy.2009.98; published online 5 August 2009

Keywords: genetic differentiation; conservation genetic monitoring; $N_{e}$ estimation; selection; marine fish; fisheries management

\section{Introduction}

The ability to detect genetic differences in time and space is critical in species management and in the quest of conserving genetic variation. Biological diversity needs to be monitored over time to permit detection of changes that can constitute threats to biological resources. Conservation genetic monitoring is particularly warranted for species subject to large-scale harvesting since such operations are known to potentially alter the genetic composition and reduce the variability of populations (Conover and Munch, 2002; Laikre et al., 2008). Aquatic organisms are the only major food resource of humans that is primarily harvested directly from wild populations (Ryman et al., 1995), and sustainability may be compromised if population differences are overlooked by management (Ruzzante et al., 2006).

Large-scale harvest operations have been demonstrated to cause genetic effects through selective removal of genotypes (Allendorf et al., 2008). Over-harvest may result in extinction of local gene pools, or may reduce the genetically effective population size $\left(N_{\mathrm{e}}\right)$ through manipulation of the demographic characteristics of populations

Correspondence: Dr LC Larsson, Division of Population Genetics, Department of Zoology, Stockholm University, Stockholm SE-106 91, Sweden.

E-mail: lena.larsson@popgen.su.se

Received 28 November 2008; revised 26 June 2009; accepted 2 July 2009; published online 5 August 2009
(Ryman et al., 1981; Laikre and Ryman, 1996). Reductions of $N_{\mathrm{e}}$ will result in elevated rates of genetic diversity loss.

$N_{\mathrm{e}}$ can be estimated by examining temporal changes in allele frequencies. Surprisingly small $N_{\mathrm{e}}$ estimates have been reported for some marine fish populations where the census population sizes $(N)$ are three to five orders of magnitude larger (Hauser and Carvalho, 2008). The reasons for such low $N_{\mathrm{e}}$ compared with $N$ have been suggested to be caused by (i) a large variance of family reproductive success ('sweepstake' recruitment; Hedgecock, 1994), (ii) high fishing pressure leading to genetic bottlenecks (Hauser et al., 2002; Hutchinson et al., 2003; Poulsen et al., 2006), (iii) unequal sex ratios (Frankham, 1995), or (iv) genetic differences between undetected subpopulations (Palstra and Ruzzante, 2008). Empirical estimates of $N_{\mathrm{e}}$ for commercially exploited marine fish range between 560-19535 (mean $N_{\mathrm{e}}=2085$, s.d.=322; Palstra and Ruzzante, 2008).

The heavily exploited Atlantic herring (Clupea haren$g u s)$ is one of the economically most important marine species. In this study, we investigate the temporal genetic stability of herring in the Skagerrak and the Baltic Sea (including the Bothnian Sea and the Bothnian Bay). Here, the estimated numbers of fish age one and older have decreased by $50 \%$ in the Bothnian Bay, increased by $290 \%$ in the Bothnian Sea, and decreased by $35 \%$ in the eastern central Baltic Sea during the past three decades (Figure 1; based on 5-year averages of the oldest compared with the most recent censuses by the Swedish National Board of Fisheries). There are no specific censuses for local 


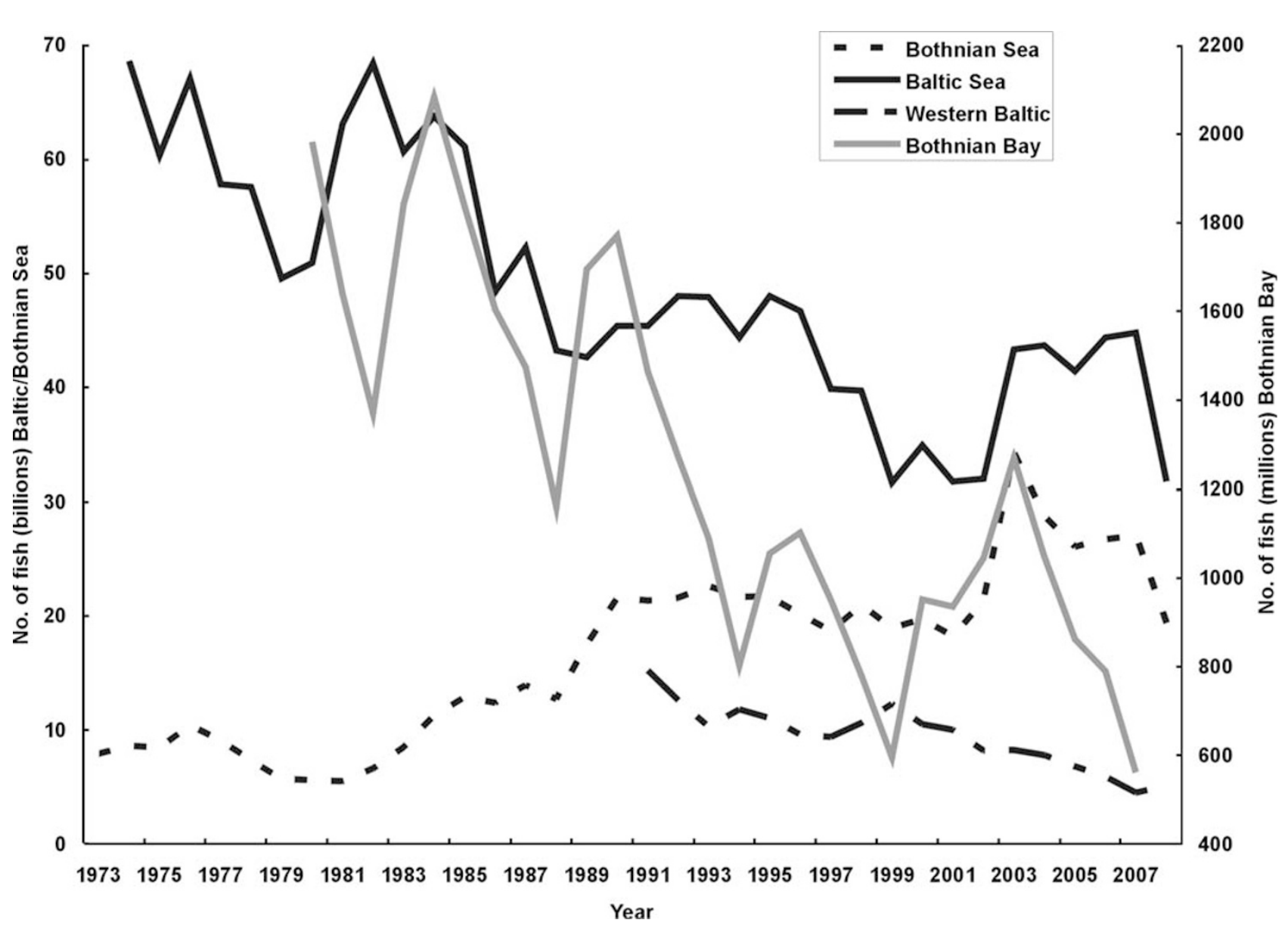

Figure 1 Estimated population census sizes for ICES subdivision 31 (Bothnian Bay), subdivision 30 (Bothnian Sea), subdivision 25-29 (Baltic Sea), and subdivision 22-24 (Western Baltic). Source: Swedish National Board of Fisheries (cf. ICES subdivisions: http://www.ices.dk/ aboutus/icesareas.asp).

Skagerrak stocks-management is merged with the western Baltic herring that feed in the Skagerrak and the census population size has decreased by $50 \%$ for this management unit since 1991 (Figure 1). Ryman et al. (1984) performed the first spatial genetic analysis of Atlantic herring in the North and Baltic Seas and the northeast Atlantic using allozymes. They found statistically significant allele frequency heterogeneities, but the amount of genetic differentiation was conspicuously small. Microsatellites give a consistent pattern; Larsson et al. (2007) showed that, with the exception for a single microsatellite locus, allozymes and microsatellites provide largely concordant information with respect to spatial genetic differentiation of Atlantic herring in this region, confirming the markedly low levels of spatial differentiation.

Jørgensen et al. $(2005,2008)$ used microsatellite loci to investigate herring structure in the Baltic Sea and observed significant associations between genetic differentiation and salinity and surface temperature. Their analyses included the outlier locus that was found to be influenced by selection by Larsson et al. (2007) and it is not clear to what extent their observed pattern is caused by this outlier.

The scope of this study is to examine the possible changes in genetic variation occurring over the past couple of decades among Atlantic herring populations in the Baltic Sea and Skagerrak. We want to determine: (i) whether there is a stable spatial pattern over the time period analyzed, (ii) whether the amount of genetic variation has changed, (iii) whether the spatio-temporal pattern differs for the locus influenced by selection as compared to the others, and (iv) what the effective population sizes are. Previously, short-term temporal stability over two consecutive sampling years have been reported in herring samples from the North Sea, Skagerrak, Kattegat, and western Baltic (Bekkevold et al., 2005; Mariani et al., 2005), but no long-term genetic study has so far been conducted for this species and estimates of effective sizes are lacking.

\section{Materials and methods}

We analyzed and compared patterns of variation for a total of 11 allozyme and nine microsatellite loci for Atlantic herring samples collected in 1979/1980 and in $2002 / 2003$. The genetic analysis includes 546 Atlantic herring collected during 1979 or 1980 and 1237 herring collected 2002 and/or 2003 at two locations in the Skagerrak, and three locations in the Baltic Sea (Figure 2; geographic coordinates are given in Table 2). Parts of the data represent material previously genotyped and published ( $c f$. Table 1). The additional samples were genotyped using the same procedures as in our previous 
studies (Ryman et al., 1984; Bekkevold et al., 2005; Larsson et al., 2007). Tissue samples of herring scored for allozymes by Ryman et al. (1984) were retained, thus

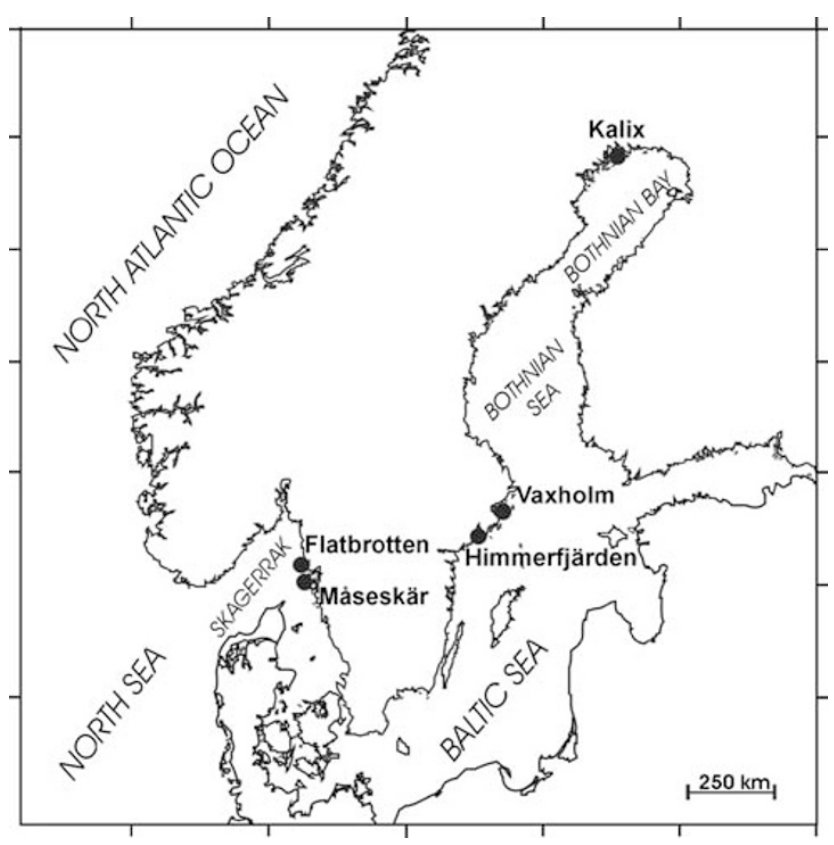

Figure 2 Geographic location of sampling sites. permitting scoring of microsatellite loci for the same individuals.

The following 11 allozyme loci were scored, where the nomenclature follows Shaklee et al. (1990), and the old locus abbreviation (to allow comparisons with results of previous studies), enzyme name, and EC number are given in parenthesis: $m A A T^{*}$ (AAT-2, aspartate aminotransferase, EC 2.6.1.1), G3PDH* (GPD-1, glycerol-3-phosphate dehydrogenase, EC 1.1.1.8), GPI* (glucosephosphate isomerase, EC 5.3.1.9), mIDHP* (IDH-2, isocitrate dehydrogenase, EC 1.1.1.42), $\mathrm{LDH}-\mathrm{1}^{*}, \mathrm{LDH}-2^{*}$ (lactate dehydrogenase, EC 1.1.1.27), $\mathrm{MDH}-4^{*}$ (malate dehydrogenase, EC 1.1.1.37), $s M E P^{*}(M E-1$, malic enzyme, EC 1.1.1.40), $m M E P^{*}(M E-2$, malic enzyme, EC 1.1.1.40), PGM-1* (phosphoglucomutase, EC 5.4.2.2, formerly EC 2.7.5.1) and SOD* (superoxide dismutase, EC 1.15.1.1). Scoring consistency with old samples was ensured by measuring the relative gel migration distances, comparing them with protocols and photographic documentation, and consulting researchers with expertise from the assays in 1979 and 1980. All these loci have earlier been shown variable in herring from this region (Andersson et al., 1981; Ryman et al., 1984; Larsson et al., 2007).

Nine tetranucleotide microsatellite loci were scored: Cha1017, Cha1020, Cha1027, Cha1202 (McPherson et al., 2001),Cpa101,Cpa111, Cpa112, Cpa113 and Cpa114 (Olsen et al., 2002). Scoring consistency among runs was ensured by analyzing two heterozygote control individuals

Table 1 Summary statistics by sampling locality and year for 11 allozyme and 9 microsatellite loci (cf. Table 2)

\begin{tabular}{|c|c|c|c|c|c|c|c|c|c|c|c|c|c|}
\hline \multirow[t]{2}{*}{ Region } & \multirow[t]{2}{*}{ Locality/Year } & \multicolumn{6}{|c|}{ Allozymes } & \multicolumn{6}{|c|}{ Microsatellites } \\
\hline & & $\mathrm{n}$ & $\mathrm{H}_{T}$ & A & $\mathrm{AR}$ & PA & $\mathrm{F}_{I S}$ & $\mathrm{n}$ & $\mathrm{H}_{T}$ & A & $\mathrm{AR}$ & PA & $\mathrm{F}_{I S}$ \\
\hline \multirow[t]{4}{*}{ Skagerrak } & $\begin{array}{l}\text { Flatbrotten } \\
58^{\circ} 20^{\prime} \mathrm{N} / 11^{\circ} 15^{\prime} \mathrm{E}\end{array}$ & & & & & & & & & & & & \\
\hline & 1979 & $100(60)^{\mathrm{a}}$ & 0.129 & 25 & 2.13 & 1 & 0.006 & $96(91)$ & 0.834 & 149 & 16.10 & 3 & $0.043^{* * *}$ \\
\hline & 2002 & 100 (99) & 0.133 & 26 & 2.16 & & -0.019 & $100(96)^{\mathrm{b}}$ & 0.833 & 147 & 15.72 & 5 & $0.030^{* *}$ \\
\hline & 2003 & $120(120)$ & 0.133 & 29 & 2.26 & 2 & 0.051 & $100(96)^{b}$ & 0.835 & 157 & 16.62 & 12 & $0.026^{*}$ \\
\hline \multirow[t]{4}{*}{ Skagerrak } & $\begin{array}{l}\text { Måseskär } \\
58^{\circ} 05^{\prime} \mathrm{N} / 11^{\circ} 19^{\prime} \mathrm{E}\end{array}$ & & & & & & & & & & & & \\
\hline & 1979 & $100(60)^{\mathrm{a}}$ & 0.126 & 27 & 2.17 & & 0.027 & $99(86)$ & 0.836 & 146 & 15.74 & 3 & $0.026^{*}$ \\
\hline & 2002 & $100(98)$ & 0.132 & 27 & 2.19 & & -0.013 & $100(93)^{\mathrm{b}}$ & 0.841 & 149 & 15.82 & 5 & $0.045^{* * *}$ \\
\hline & 2003 & $120(118)^{\mathrm{c}}$ & 0.117 & 28 & 2.15 & & 0.048 & $100(83)^{b, c}$ & 0.835 & 153 & 16.36 & 5 & 0.016 \\
\hline \multirow[t]{4}{*}{ Baltic Sea } & Himmerfjärden & & & & & & & & & & & & \\
\hline & $\begin{array}{l}59^{\circ} 04^{\prime} \mathrm{N} / 17^{\circ} 45^{\prime} \mathrm{E} \\
1979 / 1980\end{array}$ & $82(47)^{\mathrm{a}}$ & 0.122 & 25 & 2.09 & 1 & 0.065 & $98(63)$ & 0.816 & 148 & 16.06 & 7 & $0.042^{* *}$ \\
\hline & 2002 & $100(98)$ & 0.129 & 28 & 2.08 & 1 & -0.018 & 0 & - & - & - & - & - \\
\hline & 2003 & $277(268)^{c}$ & 0.123 & 34 & 2.19 & 1 & $-0.084^{* * *}$ & $100(93)^{c}$ & 0.826 & 145 & 15.38 & 5 & 0.013 \\
\hline \multirow[t]{4}{*}{ Baltic Sea } & Kalix & & & & & & & & & & & & \\
\hline & $\begin{array}{l}6348 \mathrm{~N} / 2243 \mathrm{E} \\
1980\end{array}$ & $100(100)^{\mathrm{a}}$ & 0.119 & 27 & 2.06 & & -0.034 & $100(85)$ & 0.835 & 147 & 15.68 & 4 & -0.002 \\
\hline & 2002 & $100(100)$ & 0.121 & 25 & 1.99 & & -0.016 & $100(96)$ & 0.830 & 150 & 15.98 & 3 & $0.038^{* *}$ \\
\hline & 2003 & $120(119)^{c}$ & 0.122 & 29 & 2.14 & 1 & $0.078^{*}$ & $96(71)^{\mathrm{c}}$ & 0.827 & 150 & 16.17 & 7 & $0.023^{*}$ \\
\hline \multirow[t]{4}{*}{ Baltic Sea } & Vaxholm & & & & & & & & & & & & \\
\hline & $\begin{array}{l}59^{\circ} 26^{\prime} \mathrm{N} / 18^{\circ} 18^{\prime} \mathrm{E} \\
1979\end{array}$ & $100(32)^{\mathrm{a}}$ & 0.123 & 27 & 2.24 & & -0.066 & $100(62)$ & 0.814 & 137 & 14.79 & 4 & 0.009 \\
\hline & 2002 & $100(99)$ & 0.131 & 31 & 2.37 & 1 & 0.030 & 0 & - & - & - & - & - \\
\hline & 2003 & 100 (99) & 0.130 & 26 & 2.15 & & 0.015 & $96(78)$ & 0.813 & 148 & 15.88 & 9 & 0.020 \\
\hline Total & & 1719 (1517) & 0.126 & 44 & 2.16 & 8 & 0.005 & 1285 (1093) & 0.830 & 272 & 15.87 & 72 & $0.025^{* * *}$ \\
\hline
\end{tabular}

Abbreviations: $A$, number of alleles; $A R$, mean allelic richness; $H_{\mathrm{T}}$, gene diversity; $n$, number of fish (number of complete genotypes scored in parenthesis); $P A$, number of private alleles; $F_{\text {IS }}$ quantifies the deviation from Hardy-Weinberg proportions (Weir and Cockerham, 1984).

Genotypes previously used by

${ }^{\mathrm{a}}$ Ryman et al., 1984.

bekkevold et al., 2005.

${ }^{\mathrm{c}}$ Larsson et al., 2007.

${ }^{*} P<0.05 ;{ }^{* *} P<0.01 ;{ }^{* * *} P<0.001$. 
spanning the anticipated allelic ranges on all gels, in addition to internal and external size ladders (Mariani et al., 2005). Reliability was also checked by running MICRO-CHECKER 2.2.1 (van Oosterhout et al., 2004) to test for potential stuttering, large allele drop-out, or presence of null alleles.

\section{Statistical treatment}

GENEPOP version 3.4 (Raymond and Rousset, 1995) was used for calculating F-statistics (Weir and Cockerham, 1984). FSTAT version 2.9.3.2 (Goudet, 1995, 2001) was used for calculating allelic richness, testing Hardy-Weinberg proportions, and comparing pairwise genetic differences (using the program options of 5000 randomizations and not assuming Hardy-Weinberg proportions within samples). Significances of genetic differentiation were also tested using GENEPOP version 3.4 (Raymond and Rousset, 1995) and CHIFISH version 1.3 (Ryman, 2006). All these testing approaches provided a high degree of consistency, and for brevity we only report the results from FSTAT.

GDA version 1.1 (Lewis and Zaykin, 2001) was applied to examine linkage disequilibria. Differences between older and more recent samples with respect to allelic richness as well as gene diversity were tested using both the paired $t$-test and the non-parametric Wilcoxon rank sum test. We used BOTTLENECK 1.2.02 (Cornuet and Luikart, 1996) applying the stepwise mutation model and the two-phase model for microsatellite loci (excluding Cpa112 which is an outlier), and the infinite allele model for allozyme loci, with 10000 replications to test for indications of bottlenecks. The two-phase model was run with 95\% single-step and 5\% multi-step mutations (cf. Piry et al., 1999). Wilcoxon one-tailed tests were done to test for heterozygote excess.

The presence of loci potentially affected by selection ('outliers') was investigated with the test of Beaumont and Nichols (1996), where the null distribution was created using FDIST2 (Beaumont, 2002). Concordance in $F_{\text {ST }}$ estimates among samples taken at different times was investigated using paired $t$-tests and pairwise correlation plots.

If effects of geographic separation and time are acting simultaneously, these two factors are not properly estimated with conventional gene diversity analyses. To evaluate possible interaction between them, a two-factor variance analysis is a more proper design (rather than multiple hierarchical analyses). We investigated the significance of geographical region (where the two regions consist of the Baltic Sea and Skagerrak) and time separation as well as the interaction between them using an orthogonal modification of Nei's genetic diversity analysis with a modified analysis of variance ( $c f$. Johannesson and Tatarenkov, 1997). The overall $G_{S T}$ is divided into the following components: $G_{\text {regiontotal varia- }}$ tion among regions; $G_{\text {timetotal }}$ variation among time

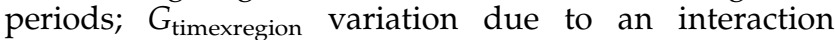
between regions and time; $G_{\text {stimeregion }}$ average variation among samples within combinations of regions and time period (residual). The samples from the locality Himmerfjärden were excluded to provide a balanced number of samples from each region. Multiple samples from the same locality 2002/2003 were pooled.
The variance effective population size $\left(N_{\mathrm{e}}\right)$ was assessed with TEMPOFS and the unbiased estimator $F_{S}$ using sample plan II, as the individuals were sampled destructively before reproduction and not returned to the populations (Jorde and Ryman, 2007). The assessment was done in two ways; first by comparing allele frequencies in the samples separated by 22-24 years ('long-term $N_{\mathrm{e}}$ '), which corresponds to approximately five herring generations. (Bias due to overlapping generations is expected to be minimized when temporal samples are spaced more than four generations apart (Waples and Yokota, 2007).) Second, we used allele frequency differences between consecutive cohorts and corrected this 'short-term $N_{\mathrm{e}}$ ' by multiplying with the ratio $C$ (a correction term obtained from life table data) divided by $G$ (generation time) according to Jorde and Ryman (1995). C and $G$ were calculated from stock and gamete production estimates in Arrhenius and Hansson (1993). $G=5.25$ for all samples, $C=11.74$ for Flatbrotten and Måseskär, 15.21 for Himmerfjärden and Vaxholm, and 16.09 for Kalix. Only cohorts in which 20 aged individuals or more had been genotyped were included when estimating $N_{\mathrm{e}}$ with the Jorde-Ryman method (1995). The cohort sample sizes and statistics are summarized in Appendix 1.

Short-term $N_{\mathrm{e}}$ was further estimated with the linkage disequilibrium method of Waples (2006) using LDNE (Waples and Do, 2008). Alleles occurring in frequencies of $<2 \%$ were pooled as rare alleles may otherwise increase bias (Waples, 2006). Confidence intervals were estimated with the jackknife method.

We also estimated long-term $N_{\mathrm{e}}$ with a likelihood method using MLNE version 2.0 (Wang and Whitlock, 2003), both assuming a migration rate $m$ of 0 (Wang, 2001) and jointly estimating $N_{\mathrm{e}}$ and $m$ (Wang and Whitlock, 2003). When jointly estimating $N_{\mathrm{e}}$ and $m$ with this method, the source population of the immigrants is assumed to be an infinitely large population with constant allele frequencies. The allele frequencies of the source population were obtained by pooling all samples from 1979/1980 and 2002/2003 except from the population for which $N_{\mathrm{e}}$ was to be estimated. The likelihood methods require a user specified upper limit for $N_{\mathrm{e}}$, which we set at 35000 after checking that similar results were obtained for limits in the range 5000-35000 (the upper bound was limited by computer capacity). Finally, we estimated $N_{\mathrm{e}}$ using Nei and Tajima's (1981) estimator $F_{\mathrm{C}}$ also using MLNE.

\section{Results}

A total of 44 alleles were observed for the allozymes and 272 for the microsatellites (Table 1), corresponding to averages of 4.0 and 30.2 alleles per locus for the two groups of loci, respectively. Missing genotypes accounted for $1.5 \%$ of the allozyme data and $3.3 \%$ of the microsatellite data distributed over all loci, likely due to the original quality of samples; retrospectively omitting individuals with one or more missing genotypes did not change the results. Expected heterozygosities were in the range 0.117-0.133 (allozymes) and 0.813-0.841 (microsatellites; Table 1). Gene diversity and allelic richness have not changed significantly over the time period examined. 
Table 2 Summary statistics for allozyme and microsatellite loci covering the five localities sampled 1979/1980 and 2002/2003 (multiple samples pooled by locality)

\begin{tabular}{|c|c|c|c|c|c|c|c|c|c|c|c|c|c|c|}
\hline \multirow[t]{2}{*}{ Locus } & \multicolumn{7}{|c|}{ Old samples-1979/1980 } & \multicolumn{7}{|c|}{ New samples_2002/2003 } \\
\hline & $\mathrm{n}$ & $\mathrm{H}_{T}$ & A & AR & $\mathrm{F}_{I S}$ & $\mathrm{~F}_{S T}$ & $\mathrm{~F}_{I T}$ & $\mathrm{n}$ & $\mathrm{H}_{T}$ & A & $\mathrm{AR}$ & $\mathrm{F}_{I S}$ & $\mathrm{~F}_{S T}$ & $\mathrm{~F}_{I T}$ \\
\hline \multicolumn{15}{|l|}{ Allozymes } \\
\hline$m A A T^{*}$ & 482 & 0.029 & 2 & 1.80 & -0.012 & -0.003 & -0.014 & 1232 & 0.035 & 4 & 1.87 & -0.018 & 0.001 & -0.018 \\
\hline$G 3 P D H^{*}$ & 419 & 0.008 & 4 & 1.38 & -0.003 & 0.001 & -0.002 & 1237 & 0.011 & 4 & 1.41 & -0.005 & $0.001^{*}$ & -0.004 \\
\hline$G P I^{*}$ & 482 & 0.535 & 7 & 5.12 & -0.027 & -0.001 & -0.027 & 1235 & 0.539 & 6 & 4.90 & 0.002 & 0.000 & 0.002 \\
\hline$m I D H P^{*}$ & 447 & 0.035 & 3 & 1.77 & -0.023 & 0.007 & -0.016 & 1230 & 0.037 & 4 & 2.16 & -0.014 & 0.002 & -0.013 \\
\hline$L D H-1^{*}$ & 362 & 0.062 & 2 & 1.98 & -0.038 & 0.004 & -0.034 & 1237 & 0.073 & 3 & 2.20 & -0.016 & 0.000 & -0.015 \\
\hline$L D H-2^{*}$ & 482 & 0.058 & 2 & 1.87 & -0.038 & $0.010^{* *}$ & -0.028 & 1237 & 0.042 & 2 & 1.83 & -0.025 & $0.005^{*}$ & -0.020 \\
\hline$M D H-4^{*}$ & 482 & 0.498 & 3 & 2.11 & 0.031 & -0.002 & 0.029 & 1233 & 0.496 & 2 & 2.00 & -0.004 & 0.002 & -0.003 \\
\hline$s M E P^{*}$ & 482 & 0.011 & 2 & 1.33 & -0.009 & 0.006 & -0.003 & 1237 & 0.006 & 4 & 1.26 & -0.003 & $0.001^{*}$ & -0.002 \\
\hline$m M E P^{*}$ & 482 & 0.021 & 4 & 1.85 & -0.006 & -0.001 & -0.007 & 1236 & 0.029 & 4 & 2.08 & -0.009 & 0.000 & -0.010 \\
\hline PGM-1* & 481 & 0.074 & 3 & 2.60 & 0.026 & -0.002 & 0.024 & 1235 & 0.101 & 6 & 2.59 & 0.018 & 0.001 & 0.018 \\
\hline$S O D^{*}$ & 447 & 0.032 & 2 & 1.70 & -0.019 & 0.003 & -0.017 & 1234 & 0.024 & 3 & 1.65 & -0.021 & $0.014^{* * *}$ & -0.006 \\
\hline Total/Mean & 459 & 0.124 & 34 & 2.14 & -0.002 & 0.000 & -0.002 & 1235 & 0.127 & 42 & 2.18 & -0.003 & $0.001^{* * *}$ & -0.001 \\
\hline \multicolumn{15}{|l|}{ Microsatellites } \\
\hline Cha1017 & 471 & 0.820 & 13 & 9.39 & $0.076^{* * *}$ & 0.000 & $0.076^{* * *}$ & 782 & 0.814 & 15 & 9.22 & $0.071^{* * *}$ & $0.004^{*}$ & $0.074^{* * *}$ \\
\hline Cha1020 & 471 & 0.914 & 28 & 16.44 & -0.013 & 0.006 & -0.007 & 776 & 0.919 & 36 & 17.60 & 0.014 & $0.003^{* * *}$ & 0.017 \\
\hline Cha1027 & 471 & 0.937 & 28 & 19.63 & $0.051^{* * *}$ & $0.008^{* * *}$ & $0.059^{* * *}$ & 778 & 0.934 & 32 & 19.07 & $0.045^{* * *}$ & $0.001^{* *}$ & $0.046^{* * *}$ \\
\hline Cha1202 & 482 & 0.778 & 14 & 10.10 & -0.022 & 0.001 & -0.022 & 779 & 0.761 & 17 & 9.74 & -0.014 & 0.000 & -0.014 \\
\hline Сpa101 & 473 & 0.914 & 27 & 17.25 & 0.017 & 0.003 & 0.020 & 773 & 0.917 & 35 & 17.50 & 0.016 & $0.001^{*}$ & $0.017^{*}$ \\
\hline Cpa111 & 464 & 0.413 & 8 & 5.60 & -0.046 & $0.010^{* * *}$ & -0.036 & 778 & 0.440 & 16 & 6.45 & 0.035 & $0.001^{* * *}$ & 0.036 \\
\hline Cpa112 & 462 & 0.858 & 35 & 15.82 & $0.061^{* * *}$ & $0.035^{* * *}$ & $0.094^{* * *}$ & 764 & 0.853 & 42 & 16.36 & $0.031^{*}$ & $0.036^{* * *}$ & $0.066^{* * *}$ \\
\hline Cpa113 & 471 & 0.933 & 22 & 17.19 & 0.015 & $0.003^{* * *}$ & 0.018 & 781 & 0.934 & 28 & 17.49 & $0.027^{* *}$ & $0.004^{* * *}$ & $0.031^{* * *}$ \\
\hline Cpa114 & 472 & 0.917 & 27 & 16.63 & $0.034^{*}$ & 0.000 & $0.034^{* *}$ & 777 & 0.917 & 28 & 16.23 & $0.020^{*}$ & 0.000 & $0.020^{*}$ \\
\hline Total/Mean & 471 & 0.832 & 202 & 14.23 & $0.023^{* * *}$ & $0.007^{* * *}$ & $0.030^{* * *}$ & 776 & 0.832 & 249 & 14.40 & $0.027^{* * *}$ & $0.006^{* * *}$ & $0.033^{* * *}$ \\
\hline All microsatellites except Cpa112 & 472 & 0.828 & 167 & 14.03 & $0.018^{* *}$ & $0.003^{* * *}$ & $0.022^{* * *}$ & 778 & 0.829 & 207 & 14.16 & $0.027^{* * *}$ & $0.002^{* * *}$ & $0.028^{* * *}$ \\
\hline $\begin{array}{l}\text { All allozymes and microsatellites } \\
\text { except Cpa112 }\end{array}$ & 464 & 0.420 & 201 & 7.14 & $0.015^{* *}$ & $0.003^{* * *}$ & $0.018^{* * *}$ & 1042 & 0.423 & 249 & 7.22 & $0.020^{* * *}$ & $0.002^{* * *}$ & $0.022^{* * *}$ \\
\hline
\end{tabular}

Abbreviations: $A$, number of alleles; $A R$, mean allelic richness; $H_{\mathrm{T}}$, total gene diversity; $n$, number of individuals genotyped.

$F_{\mathrm{ST}}$ represents the fixation index quantifying genetic differentiation over the sampling localities at the two time periods. $F_{\mathrm{IT}}$ and $F_{\mathrm{IS}}$ measure the degree of deviation from Hardy-Weinberg expectations in the total material and within localities, respectively (Weir and Cockerham, 1984).

${ }^{*} P<0.05 ;{ }^{* *} P<0.01 ;{ }^{* * *} P<0.001$.

\section{Conformance to Hardy-Weinberg expectations}

When considering each locus-location combination separately only one of 128 allozyme $F_{\mathrm{IS}}$ values indicated significant deviation from Hardy-Weinberg expectations, and it did not remain significant after applying the Bonferroni correction (critical $P=0.05 / 128=0$. 0004). For the microsatellites, 20 of 117 locus/locality $F_{\text {IS }}$ values showed significance, but they did not persist after Bonferroni correction (critical $P=0.05 / 117=0.0004$ ). When pooling the information from multiple loci and/ or samples, there is a significant heterozygote deficiency at the microsatellites $\left(F_{\mathrm{IS}}=0.025, P<0.001\right)$, but not at the allozymes $\left(F_{\text {IS }}=0.005\right.$; Table 1$)$. There was no evidence for large allele drop-out or stuttering for any microsatellite locus according to the MICRO-CHECKER results. The heterozygote deficiencies were most prevalent for Cha1017 and Cha1027; the locus specificity indicates possible presence of null alleles rather than a Wahlund effect. These two loci do not appear to be outliers in other respects and omitting them did not change estimates of differentiation $\left(F_{\mathrm{ST}}\right)$.

Testing for linkage disequilibrium, bottleneck, and selection

There are no apparent indications of linkage disequilibria. There are a total of 2580 pairwise locus combinations (20 loci) within localities. Of these, 78 showed significant deviation from linkage equilibrium (c. $3 \%$ of the tests) when accounting for potential within locus Hardy-Weinberg deviations. None of the significances remained after Bonferroni correction. There are no indications of bottlenecks in any of the samples for neither allozymes $(0.90<P<0.98)$ nor microsatellites (two-phase model: $0.37<P<0.90$; stepwise mutation model: $0.63<P<0.99$ ).

The outlier analysis using the method of Beaumont and Nichols (1996) identifies the microsatellite locus Cpa112 as an outlier whereas the other loci show no indication of selection influence. This outlier locus has a conspicuously higher $F_{\mathrm{ST}}$ than other loci, indicating divergent selection, concurring with the observation by Larsson et al. (2007). Two alleles, Cpa112(306) and Cpa112(344), exhibit higher allele frequencies in regions with lower salinity. This is seen in the older samples as well as in the newer ones. As Cpa112 appears to be influenced by selection, this locus is excluded in some of the subsequent analyses.

\section{Spatial and temporal genetic structure}

Overall, there are no large genetic heterogeneities. Although weak, there is a significant spatial genetic difference both in the older and the newer samples (Table 2). $F_{\mathrm{ST}}$ over all the 19 loci (excluding Cpa112) and five localities is 0.003 ( $95 \% \mathrm{CI}=0.001-0.005)$ for the old 
Table 3 Significance levels of temporal changes in Atlantic herring samples based on 19 loci (the outlier Cpa112 excluded)

\begin{tabular}{|c|c|c|c|c|}
\hline \multirow[t]{3}{*}{ Locality } & \multicolumn{4}{|c|}{ Temporal changes } \\
\hline & \multirow{2}{*}{$\begin{array}{c}\text { Long term } \\
\text { 1979/1980-2002/2003 }\end{array}$} & \multirow{2}{*}{$\begin{array}{l}\text { Short term } \\
\text { 2002-2003 }\end{array}$} & \multicolumn{2}{|c|}{ Between cohorts ${ }^{\mathrm{a}}$} \\
\hline & & & Old cohorts & New cohorts \\
\hline Flatbrotten & NS & $*$ & $* *$ & $* * *$ \\
\hline Måseskär & $* * *$ & NS & NS & NS \\
\hline Skagerrak samples & $* * *$ & $*$ & $* *$ & $* * *$ \\
\hline Himmerfjärden $^{\mathrm{b}}$ & NS & NS & - & NS \\
\hline Vaxholm ${ }^{b}$ & $* * *$ & NS & NS & NS \\
\hline Kalix & NS & NS & - & NS \\
\hline Baltic samples & NS & NS & NS & $* * *$ \\
\hline
\end{tabular}

Abbreviation: NS, non-significant.

Testing among present cohorts, number of cohorts vary between localities (cf. Appendix 1).

bSample from 2002 was only genotyped for allozymes.

${ }^{*} P<0.05 ;{ }^{* *} P<0.01 ;{ }^{* * *} P<0.001$.

Table 4 Two-factor variance analysis (orthogonal design) of gene diversity at 19 loci (excluding Cpa112) for eight samples of Atlantic herring from two time periods distributed over four localities and two regions (Baltic Sea and Skagerrak)

\begin{tabular}{|c|c|c|c|c|c|c|c|c|}
\hline Locus & $n$ & $\mathrm{H}_{S}$ & $\mathrm{H}_{T}$ & $\mathrm{G}_{S T}$ & $\mathrm{G}_{\text {regiontotal }}$ & $\mathrm{G}_{\text {timetotal }}$ & $\mathrm{G}_{\text {timexregion }}$ & $\mathrm{G}_{\text {stimeregion }}$ \\
\hline$m A A T^{*}$ & $100-220$ & 0.030 & 0.030 & 0.0023 & $0.0016^{*}$ & 0.0001 & 0.0001 & 0.0006 \\
\hline$G 3 P D H^{*}$ & $72-220$ & 0.010 & 0.010 & 0.0043 & 0.0014 & 0.0001 & 0.0005 & 0.0024 \\
\hline$G P I^{*}$ & $100-220$ & 0.537 & 0.538 & $0.0032^{*}$ & 0.0005 & 0.0001 & 0.0009 & 0.0018 \\
\hline$m I D H P^{*}$ & $100-220$ & 0.042 & 0.042 & $0.0052^{\dagger}$ & 0.0001 & 0.0003 & 0.0004 & 0.0044 \\
\hline$L D H-1^{*}$ & $60-220$ & 0.058 & 0.058 & 0.0034 & 0.0007 & 0.0008 & 0.0000 & 0.0019 \\
\hline$L D H-2^{*}$ & $100-220$ & 0.053 & 0.054 & $0.0104^{* *}$ & $0.0063^{*}$ & 0.0008 & 0.0001 & 0.0031 \\
\hline$M D H-4^{*}$ & $100-220$ & 0.495 & 0.497 & 0.0037 & $0.0021^{\dagger}$ & 0.0000 & 0.0001 & 0.0015 \\
\hline$s M E P^{*}$ & $100-220$ & 0.007 & 0.007 & $0.0081^{\dagger}$ & 0.0019 & 0.0002 & 0.0005 & 0.0055 \\
\hline$m M E P^{*}$ & $100-220$ & 0.023 & 0.023 & 0.0026 & 0.0004 & 0.0007 & 0.0001 & 0.0015 \\
\hline$P G M-1^{*}$ & $100-220$ & 0.089 & 0.090 & $0.0040^{*}$ & 0.0000 & $0.0019^{\dagger}$ & 0.0006 & 0.0014 \\
\hline$S O D^{*}$ & $100-220$ & 0.033 & 0.034 & $0.0087^{* *}$ & $0.0051^{*}$ & 0.0009 & 0.0002 & 0.0025 \\
\hline Cha1017 & 93-199 & 0.811 & 0.816 & $0.0064^{\dagger}$ & 0.0028 & 0.0002 & 0.0007 & 0.0028 \\
\hline Cha1020 & 89-200 & 0.908 & 0.915 & $0.0077^{* * *}$ & 0.0034 & 0.0004 & 0.0006 & 0.0033 \\
\hline Cha1027 & 94-200 & 0.929 & 0.937 & $0.0084^{* * *}$ & 0.0021 & 0.0008 & 0.0016 & 0.0039 \\
\hline Cha1202 & 92-199 & 0.764 & 0.768 & $0.0045^{* *}$ & $0.0021^{\dagger}$ & 0.0006 & 0.0002 & 0.0018 \\
\hline Cpa101 & 89-199 & 0.912 & 0.917 & $0.0051^{\dagger}$ & 0.0011 & 0.0004 & 0.0010 & 0.0025 \\
\hline Cpa111 & 93-200 & 0.430 & 0.433 & $0.0080^{* * *}$ & 0.0004 & 0.0006 & 0.0012 & 0.0058 \\
\hline Cpa113 & 95-200 & 0.926 & 0.932 & $0.0062^{* * *}$ & 0.0026 & 0.0003 & 0.0008 & 0.0024 \\
\hline Cpa114 & 90-197 & 0.913 & 0.917 & 0.0045 & 0.0003 & 0.0006 & 0.0006 & 0.0030 \\
\hline Average & & 0.420 & 0.422 & $0.0059^{* * *}$ & $0.0019^{*}$ & 0.0004 & 0.0008 & 0.0028 \\
\hline
\end{tabular}

Abbreviations: $G_{\mathrm{ST}}$, overall variation among samples; $H_{\mathrm{S}}$, average heterozygosity within samples; $H_{\mathrm{T}}$, total heterozygosity; $n$, sample sizes. $G_{\text {ST }}$ was further divided into the following parameters: $G_{\text {regiontotal }}$ variation among regions; $G_{\text {timetotal }}$ variation among time periods; $G_{\text {timexregion }}$ variation due to an interaction between regions and time; $G_{\text {stimeregion }}$ average variation among samples within combinations of regions and time period (residual). For further details see text and Johannesson and Tatarenkov (1997).

${ }^{\dagger} 0.05<P<0.1 ;{ }^{*} P<0.05 ;{ }^{* *} P<0.01 ;{ }^{* * *} P<0.001$.

samples and $0.002(95 \% \mathrm{CI}=0.001-0.003)$ for the new ones, and both are highly significant. At both occasions is the major part of the divergence due to differences between the Baltic and the Skagerrak where multilocus $F_{\mathrm{ST}}$ is 0.003 (old samples) and 0.002 (new samples) as well. Within the Skagerrak, we find an $F_{\mathrm{ST}}=0.001$, which is significant in the new samples (uncorrected $P=0.003$ ) but not in the old ones. There is spatial genetic heterogeneity among the three localities within the Baltic in 1979/1980 (multilocus $F_{\mathrm{ST}}=0.002^{* * *}$ ) and $2002 / 2003$ (multilocus $F_{\mathrm{ST}}=0.001^{* * *}$ ). Overall pairwise multilocus $F_{\mathrm{ST}} \mathrm{S}$ ranged between 0-0.006 for the 1979/1980 samples and between $0-0.008$ for the $2002 / 2003$ samples.

With respect to temporal heterogeneity, there are both short-term and long-term differences at some localities (Table 3, Appendix 1). Multilocus $F_{\mathrm{ST}}$ ranged between 0-0.004 over time within the localities. The samples from Flatbrotten 2002 vs 2003 show a significant short-term temporal shift $\left(F_{\mathrm{ST}}=0.001, P=0.036\right)$. However, this low significance level warrants dismissal of the difference if a Bonferroni correction is applied. Long-term temporal changes were found when comparing the old samples with newer ones both at Måseskär $\left(F_{\mathrm{ST}}=0.002, P<0.001\right)$ and Vaxholm $\left(F_{\mathrm{ST}}=0.004, P<0.001\right)$. There is an overall long-term difference when $\chi^{2}$ test results for temporal heterogeneity at each locality are combined $(P=0.002$; the outlier Cpa112 excluded; Ryman et al., 2006). Significant differences between consecutive cohorts were only observed at Flatbrotten (old cohorts $F_{\mathrm{ST}}=0.005$, $P=0.002$; new cohorts $F_{\mathrm{ST}}=0.003, P<0.001$ ).

In the orthogonal analysis of variance, there is no interaction between the two factors time and region, nor is there a significant effect of time (Table 4). The only significant orthogonal component is the variation among regions $\left(G_{\text {regiontotal }}=0.0019\right.$; multilocus $\left.P=0.014\right)$ that explains $32 \%$ of the overall genetic variation among 


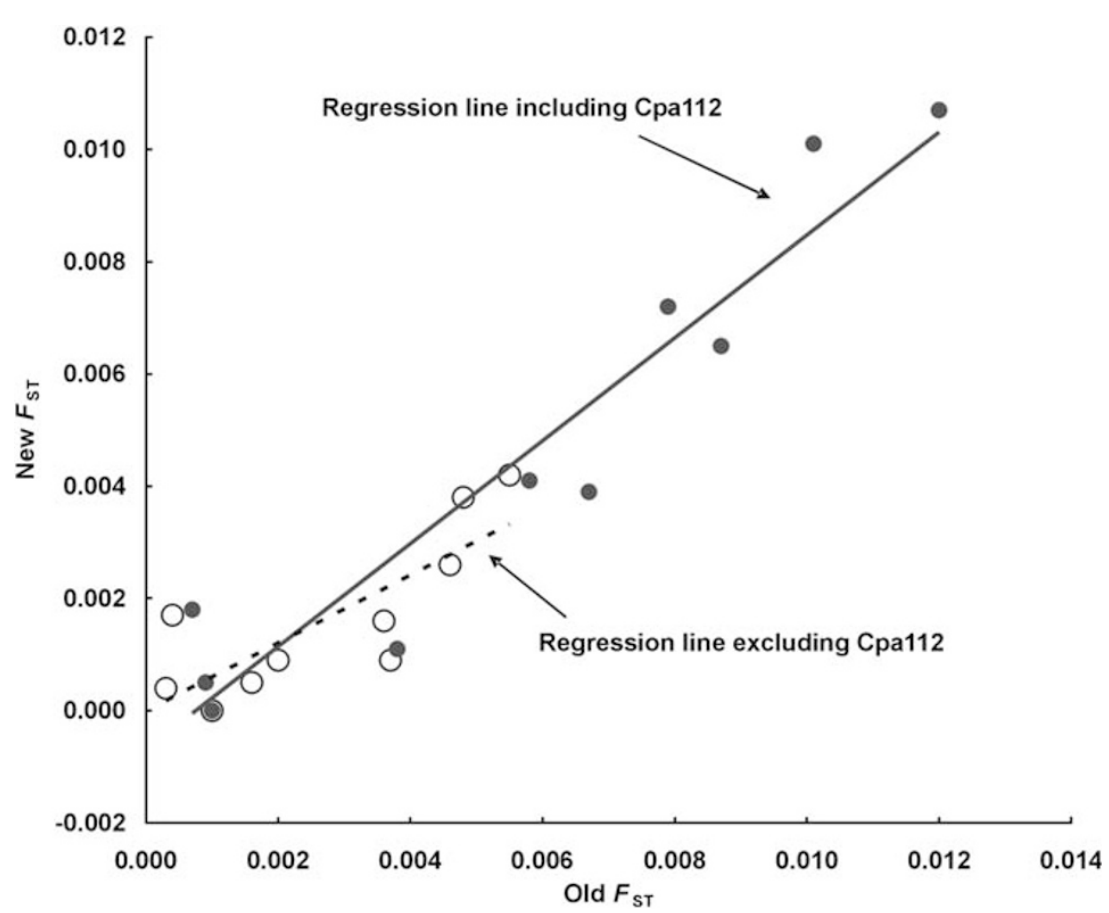

Figure 3 Pairwise multilocus $F_{\mathrm{ST}}$ estimates for the old samples compared with the pairwise multilocus $F_{\mathrm{ST}}$ estimates in the new samples. When Cpa112 is included (filled circles) $r^{2}=0.91(P<0.001)$, with Cpa112 excluded (open circles) $r^{2}=0.65(P=0.005)$.

samples $\left(G_{S T}=0.0059\right)$. The variation among the time periods is concordant for microsatellites and allozymes and only explains $6.8 \%$ (non-significant).

The spatial structure does not appear to have changed over the time interval examined, and the similarity is particularly obvious at Cpa112 (Figure 3). There is a strong and highly significant positive correlation between the 10 pairwise $F_{\mathrm{ST}} \mathrm{S}$ among localities of old and new samples $\left(r^{2}=0.91, P<0.001\right)$. Cpa112 contributes primarily to this correlation computed over all loci, but the effect remains also when excluding this outlier locus $\left(r^{2}=0.65, P=0.005\right)$.

\section{Estimates of $N_{e}$}

Under the assumption of $m=0$, the observation of a significant temporal allele frequency change is necessary to obtain an estimate of effective size with a finite upper confidence limit. The short-term temporal shift at Flatbrotten is significant, as are the long-term changes at Måseskär and Vaxholm (Table 3), whereas no temporal changes can be observed at Himmerfjärden or Kalix. Pooling samples within the Baltic and Skagerrak separately yielded significant temporal changes in Skagerrak but only short-term temporal change between the newer cohorts in the Baltic.

The short-term $N_{\mathrm{e}}$ estimate for Flatbrotten yields $N_{\mathrm{e}}=138 \quad(95 \% \mathrm{CI}=63$-infinity) based on consecutive cohorts sampled in 1979 and $N_{\mathrm{e}}=356(95 \% \mathrm{CI}=178$ infinity) based on cohorts sampled in 2002 and 2003 (Table 5). The linkage disequilibrium method estimates somewhat higher although similar effective population sizes. The samples retrieved from Skagerrak in 2002 and 2003 yield an estimated short-term $N_{\mathrm{e}}=1806 \quad(95 \%$ $\mathrm{CI}=981-7977)$ with the linkage disequilibrium method (Table 5).
On the basis of the long-term allele frequency change with the unbiased estimator $F_{\mathrm{S}}$, the $N_{\mathrm{e}}$ estimate for Vaxholm is 419 (95\% CI=275-879) and the corresponding estimate for Måseskär is 630 with an upper limit of infinity (Table 6). The lower confidence limits for the other localities are approximately in the low thousands. $N_{\mathrm{e}}$ point estimates obtained with the $F_{\mathrm{C}}$ estimator are alike the ones with $F_{\mathrm{S}}$. The likelihood method results in very similar $N_{\mathrm{e}}$ estimates, when assuming $m=0$, as the other approaches based on longterm shifts (Table 6). The long-term $N_{\mathrm{e}}$ estimate for Vaxholm is 711 (95\% CI =380-2418), and for Måseskär 1552 (95\% CI $=755-11691)$. For the other localities, the 95\% upper bound is greater than the limit imposed on this method.

When jointly estimating $N_{\mathrm{e}}$ and $m$, the observed allele frequency change is assumed to reflect the effects of both genetic drift and migration, resulting in lower estimates of $N_{\mathrm{e}}$. When using this approach, an upper confidence limit is obtained for all samples, with the lowest estimate at Vaxholm $\left(N_{\mathrm{e}}=276,95 \% \mathrm{CI}=155-556\right)$. Vaxholm and Måseskär also have the highest migration rate estimates of $3-5 \%$.

\section{Discussion}

Although Baltic Sea and Skagerrak herring is heavily fished, we cannot see indications of major changes in the spatial genetic structure or amount of genetic diversity in these regions between 1979/1980 and $2002 / 2003$. Spatial genetic structure remains weak with overall $F_{\mathrm{ST}}=0.003$ (95\% CI $\left.=0.001-0.005\right)$ among locations for the older samples and $F_{\mathrm{ST}}=0.002 \quad(95 \%$ $\mathrm{CI}=0.001-0.003)$ for the newer ones. The major component of this divergence refers to differences between the two major regions Baltic vs Skagerrak in line with earlier 
Table 5 Estimates of short-term effective population size $\left(N_{e}\right)$ for Atlantic herring using $(i)$ the temporal method accounting for overlapping generations and (ii) the linkage disequilibrium method

\begin{tabular}{lccc}
\hline Locality & Sample year(s) & $\begin{array}{c}\text { Consecutive cohorts } \\
\text { (Jorde } \begin{array}{c}\text { Ryman, 1995, 2007) } \\
N_{e}\end{array}\end{array}$ & $\begin{array}{c}\text { Linkage disequilibrium } \\
\text { (Waples, 2006) } \\
N_{e}\end{array}$ \\
\hline Flatbrotten & 1979 & $138(63-\infty)$ & $716(309-\infty)$ \\
Måseskär & $2002 / 2003$ & $356(178-\infty)$ & $3816(861-\infty)$ \\
& 1979 & $\infty(152-\infty)$ & $\infty(1419-\infty)$ \\
Skagerrak samples & $2002 / 2003$ & $\infty(1030-\infty)$ & $1981(754-\infty)$ \\
Himmerfjärden & 1979 & $497(169-\infty)$ & $\infty(1153-\infty)$ \\
Kalix & $2002 / 2003$ & $\infty(1951-\infty)$ & $1806(981-7977)$ \\
Vaxholm & $1979 / 1980$ & NA & $\infty(0-\infty)$ \\
Baltic samples & $2002 / 2003$ & $448(121-\infty)$ & $\infty(1171-\infty)$ \\
& 1980 & NA & $\infty(663-\infty)$ \\
& $2002 / 2003$ & $417(163-\infty)$ & $4063(841-\infty)$ \\
$1553(390-\infty)$ & $\infty(859-\infty)$ \\
\hline
\end{tabular}

Abbreviation: NA, not available (ages were missing).

95\% CI are given in parentheses. See text for details.

Table 6 Estimates of long-term effective population size $\left(N_{e}\right)$ and migration rate $(m)$ based on temporally separated samples of Atlantic herring from five locations

\begin{tabular}{|c|c|c|c|c|c|}
\hline \multirow[t]{3}{*}{ Locality } & \multicolumn{3}{|c|}{ Method (assuming $m=0$ ) } & \multirow{2}{*}{\multicolumn{2}{|c|}{$\begin{array}{l}\text { Method (assuming } m>0 \text { ) } \\
\text { hood (Wang and Whitlock, 2003) }\end{array}$}} \\
\hline & \multirow{2}{*}{$\begin{array}{c}\mathrm{F}_{\mathrm{s}} \text { (Jorde and } \\
\text { Ryman, 2007) } \\
\mathrm{N}_{e}\end{array}$} & \multirow{2}{*}{$\begin{array}{c}\text { Likelihood } \\
\text { (Wang, 2001) } \\
\mathrm{N}_{e}\end{array}$} & \multirow{2}{*}{$\begin{array}{c}\mathrm{F}_{c}(\mathrm{Nei} \text { and } \\
\text { Tajima, 1981) } \\
\mathrm{N}_{e}\end{array}$} & & \\
\hline & & & & $\mathrm{N}_{e}$ & $\mathrm{~m}$ \\
\hline Flatbrotten & $\infty(949-\infty)$ & $>35000(2169->35000)$ & $\infty$ & $1515(671-6577)$ & $0.009(<0.001-0.021)$ \\
\hline Måseskär & $630(288-\infty)$ & 1552 (755-11 691) & 795 & $543(311-1158)$ & $0.027(0.011-0.046)$ \\
\hline Skagerrak samples & $2914(704-\infty)$ & $9576(2602->35000)$ & 2834 & $1582(866-3600)$ & $0.008(0.005-0.015)$ \\
\hline Himmerfjärden $^{a}$ & $\infty(2267-\infty)$ & $>35000(1333->35000)$ & $\infty$ & $1624(577-6725)$ & $0.009(<0.001-0.027)$ \\
\hline Kalix & $\infty(2570-\infty)$ & $>35000(2753->35000)$ & $\infty$ & 3062 (953-5785) & $0.004(<0.001-0.015)$ \\
\hline Vaxholm $^{\mathrm{a}}$ & $419(275-879)$ & $711(380-2418)$ & 492 & $276(155-556)$ & $0.049(0.023-0.099)$ \\
\hline Baltic samples & $\infty(3775-\infty)$ & $12280(3345->35000)$ & 6119 & 2146 (1194-4409) & $0.007(0.004-0.012)$ \\
\hline
\end{tabular}

Note that an upper limit of 35000 is imposed on the likelihood methods. 95\% CI are given in parentheses. See text for details.

a Sample from 2002 was only genotyped for allozymes and was therefore excluded.

studies (Ryman et al., 1984; Bekkevold et al., 2005; Ruzzante et al., 2006; Larsson et al., 2007). The stability of the spatial structure is supported by the strong correlation between old and new samples with respect to multilocus $F_{\mathrm{ST}} \mathrm{S}$ among pairwise localities when considering the 19 loci presumed to be selectively neutral $\left(r^{2}=0.65\right)$.

\section{Temporal stability of genetic structure}

There are indications of long-term temporal allele frequency change within the total Baltic Sea-Skagerrak area. These long-term genetic changes are mainly observed at Måseskär in the Skagerrak and Vaxholm in the Baltic. We also observe a short-term genetic change at Flatbrotten in the Skagerrak. Short-term allele frequency shifts were not observed in an earlier study on herring in this area (Bekkevold et al., 2005). A difference between cohorts (such as noted at Flatbrotten in this study) has also been observed in the North Sea (Mariani et al., 2005).

We have previously shown that the microsatellite locus Cpa112 is subject to selection or closely linked to a locus under selection (Larsson et al., 2007). Our present results do not contradict these findings. We observe a conspicuously stronger correlation of pairwise $F_{\mathrm{STS}}$ among sampling localities for Cpa112 $\left(r^{2}=0.93, P<0.001\right)$ than for any of the presumed neutral loci $\left(r^{2}\right.$ ranging from 0.0003 to 0.476 with $P$-values between 0.03 and 0.96 ). Thus, our present results suggest that the selective regime has not changed over the 24-year period studied here, and that there has not been enough migration to counteract natural selection.

Although of obvious interest from a conservation management perspective, investigations of the stability of spatial structure of marine fish are relatively scarce. What was previously considered to represent spatial structuring in the European eel (Anguilla anguilla), has since been suggested to reflect temporal heterogeneities (Dannewitz et al., 2005). In line with the results of this study, temporally stable spatial structuring has been reported in Atlantic cod (Gadus morhua) populations, despite large reductions in census sizes (Ruzzante et al., 2001; Poulsen et al., 2006). A close relative of the herring, the European sardine or pilchard (Sardina pilchardus), was also found to exhibit stable, although very weak, spatial structure (Laurent and Planes, 2007). 
Genetic diversity

We could not detect any significant change in genetic diversity measured as expected heterozygosity or allelic richness over the approximate two decades studied here. Herring has a long history of exploitation and the fisheries have been characterized by fluctuating abundances (MacKenzie et al., 2002), making it difficult to know what to expect in regards to changes of genetic diversity. We cannot make comparisons with nonexploited populations like Hauser et al. (2002) did with the New Zealand snapper (Pagrus auratus) for which they found a significant decrease in heterozygosity and mean number of alleles.

Similarly, a decrease in genetic diversity was detected in a comparison before and after heavy exploitation of orange roughy (Hoplostethus atlanticus; Smith et al., 1991). In contrast, there was no significant loss of genetic diversity over 40 years and with declining population sizes in the thornback ray (Raja clavata; Chevolot et al., 2008). However, as with our herring data, these samples do not predate major exploitation so genetic diversity may have been lost before sampling. Genetic diversity can also be lost but subsequently increase due to immigration (e.g. Hutchinson et al., 2003). We may be unaware of declines and subsequent increases in diversity (or vice versa) occurring between our sampling occasions. Long-term sequential sampling schemes (although typically financially and logistically difficult to sustain) can therefore be essential when examining temporal trends to detect possible changes of genetic diversity related to exploitation.

Large populations have a higher capacity to retain rare alleles than small ones. Therefore, when a large population decreases drastically, there is a disproportionate risk of losing alleles compared with small populations experiencing a similar relative decline. During this study period, herring populations in for example the Bothnian Bay have declined from two billions to one billion (Figure 1). At mutation-drift equilibrium, assuming a mutation rate of $10^{-4}$, and an $N_{\mathrm{e}} / N$ ratio between $0.001-1 \%$, such a decline is expected to result in at least a 50\% reduction of the number of alleles (cf. Ryman et al., 1995). However, we did not find any reduction of allelic richness (Table 2). Possible explanations for this include (i) that equilibrium has not yet been reached, (ii) previous fluctuations of population size before our study have reduced the number of alleles (e.g. Grant and Bowen, 1998), or (iii) lack of power to detect loss of low frequency alleles. Obviously, the populations cannot be in mutation-drift equilibrium as they are still declining, and the relative importance of the two other explanations cannot be determined.

\section{Short-term effective population size}

Using allele frequency shifts between consecutive cohorts and correcting for overlapping generations provides smaller point estimates of $N_{\mathrm{e}}$ and smaller values for the lower confidence limits than the linkage disequilibrium method (Table 5). It is uncertain what effect overlapping generations (as is the case for Atlantic herring) can have on the linkage disequilibrium method. Regardless, it is not possible to separate the estimates from infinity, and this is also true for Flatbrotten where we observe a significant short-term temporal allele frequency shift. There is no compelling evidence for either an increase or decrease of $N_{\mathrm{e}}$ over time.

\section{Long-term effective population size}

Overall, the effective population sizes over the 24-year period studied here appear to be rather large, and the upper confidence intervals indicate that many of these estimates cannot be separated from infinity (Table 6). It is difficult to estimate $N_{\mathrm{e}}$ for large populations (Waples, 1989; Skalski, 2007); the sample sizes in such situations need to be large as well (Luikart et al., 1999; Ovenden et al., 2007). Nevertheless, our $N_{\mathrm{e}}$ estimates are still relatively small compared with the estimated census sizes, which are in the billions for these management areas (cf. Figure 1). Conspicuously small $N_{\mathrm{e}} / N$ ratios have been observed in several marine fishes (Hauser and Carvalho, 2008), and our present observation is consistent with those findings.

Allele frequency changes at the localities Måseskär and Vaxholm are reflected in relatively small $N_{\mathrm{e}}$ estimates of for example 630 and 419 (using the $F_{\mathrm{S}}$ estimator of Jorde and Ryman, 2007). For Måseskär, the upper limit is infinity with this estimator, but for Vaxholm the 95\% $\mathrm{CI}=275-879$. The other methods consistently estimate a low effective size for this locality. Why would there be a small $N_{\mathrm{e}}$ in Vaxholm? One explanation would be that a local herring population exists in this area that is relatively small. Physically isolated and genetically differentiated populations have been observed both in Atlantic and Pacific herring (Clupea pallasi; McPherson et al., 2004; Small et al., 2005).

An alternative explanation for the low $N_{\mathrm{e}}$ estimate at Vaxholm is that the 'large' allele frequency shifts is not caused by genetic drift but by immigration from, or replacement by, a genetically distinct population (genetic swamping). We do not consider this explanation unlikely; $F_{\mathrm{ST}}$ between Vaxholm 1979 and 2002/2003 is 0.004, which is of the same magnitude as observed among localities within the Baltic.

\section{Demographic independence}

Despite the minuscule amount of spatial differentiation between localities, the herring populations in the Baltic-Skagerrak regions may still be demographically independent. Demographic independence between populations is suggested to occur at migration rates of $10 \%$ or less (Hastings, 1993; Palsbøll et al., 2007). Assuming migration-drift equilibrium, we expect $F_{\mathrm{ST}} \approx 1 /\left(4 N_{\mathrm{e}} m+1\right)$ (Crow and Kimura, 1970). This means that our $F_{\mathrm{ST}}$ estimates of c. 0.002 both within and between regions would correspond to about 100 genetically effective migrants per generation or more, implying demographic independence at effective population sizes of 1000 or more. Most of our $N_{\mathrm{e}}$ estimates seem to meet this criterion. Similarly, using the MLNE approach we estimate migration rates to be only a few percentages or less (Table 6).

The subtle genetic population structure found in this study does not challenge the view of a metapopulation structure in herring proposed by McQuinn (1997) where local population integrity is maintained by repeat but not necessarily natal homing to spawning areas; recruits learn migration patterns from adults. The genetic population structure observed in these herring samples 
can also conform to a 'mixed structure metapopulation model' (Harrison and Taylor, 1997). In this model, most subpopulations are connected by high rates of exchange, whereas more isolated subpopulations occur within the metapopulation. Both geographic isolation and differences in timing of spawning can facilitate distinctiveness. The evidence is not overwhelming, but the mixed structure metapopulation model can explain the local allele frequency shifts at Vaxholm and Måseskär and the resulting relatively small local effective population sizes.

\section{Conclusions}

In summary, we conclude:

(1) The amount of gene diversity and the number of alleles in Atlantic herring in Swedish waters have not decreased even though the census population sizes have declined during the time period investigated here.

(2) The spatial structure of the investigated Atlantic herring populations did not change between 1979/ 1980 and 2002/2003. The differentiation is weak with $F_{\mathrm{ST}}=0.003 \quad(95 \% \quad \mathrm{CI}=0.001-0.005)$ for the older samples and $F_{\mathrm{ST}}=0.002(95 \% \mathrm{CI}=0.001-0.003)$ for the newer ones.

(3) Temporal genetic changes are fairly small and spatial genetic structure, particularly between the two main regions (Baltic Sea vs Skagerrak), accounts for most of the allele frequency variation. Of the overall genetic variation among samples $\left(G_{\mathrm{ST}}=0.0059\right)$, $32 \%$ is explained by the difference between the Baltic and the Skagerrak $(P=0.014)$, whereas only $6.8 \%$ is explained by temporal genetic differences (nonsignificant).

(4) Although there is little long-term temporal allele frequency change within the total area, such changes are observed at Måseskär in the Skagerrak and Vaxholm in the Baltic. Short-term temporal changes are only observed at Flatbrotten in the Skagerrak.

(5) Generally, the effective population sizes appear to be rather large and can in many cases not be separated from infinity. The exceptions are Måseskär and Vaxholm where the long-term temporal genetic changes are reflected in relatively small local $N_{\mathrm{e}}$ estimates. There is no compelling evidence for either an increase or decrease of $N_{\mathrm{e}}$ over time.

(6) The generally large effective population sizes, in combination with our estimates of low degrees of genetic divergence, and low migration rates support the potential for demographic independence among populations in this region.

(7) The previously identified influence of selection at the microsatellite locus Cpa112 remains stable over the 24-year period studied here.

\section{Acknowledgements}

We thank Subject Editor Roger Butlin, Robin Waples, and two anonymous reviewers for valuable comments and suggestions on the paper. We also thank Per Erik Jorde, Gunnar Ståhl, Teija Aho, and Max Cardinale who provided helpful suggestions and information. We thank Arne Berggren, Vaxholm, Sweden, Börje Larsson, Nynäshamn, Sweden, Thomas Hasselborg, Birgitta Krischans- son, and Marianne Johansson at the Swedish National Board of Fisheries for assistance in obtaining and processing samples. This work is affiliated with the research project HERGEN (http://www.hull.ac.uk/ hergen/) funded by the European Union within the Framework Programme 5, and the efforts of the joint consortium are acknowledged. Financial support was provided by Formas-the Swedish Research Council for Environment, Agricultural Sciences and Spatial Planning (LL, CA, NR), the Swedish Research Council VR (LL, CA, NR), Sven and Lilly Lawski's Fund (LCL), Carl Tryggers Stiftelse (LL), and Stockholm Marine Research Centre (LCL). Parts of the analyses were conducted within the framework of the BaltGene project funded by BONUS Baltic Organisations' Network for Funding Science EEIG.

\section{References}

Allendorf FW, England PR, Luikart G, Ritchie PA, Ryman N (2008). Genetic effects of harvest on wild animal populations. Trends Ecol Evol 23: 327-337.

Andersson L, Ryman N, Rosenberg R, Ståhl G (1981). Genetic variability in Atlantic herring (Clupea harengus harengus): description of protein loci and population data. Hereditas 95: 69-78.

Arrhenius F, Hansson S (1993). Food consumption of larval, young and adult herring and sprat in the Baltic Sea. Mar Ecol Prog Ser 96: 125-137.

Beaumont MA, Nichols RA (1996). Evaluating loci for use in the genetic analysis of population structure. Proc $R$ Soc $B$ 263: 1619-1626.

Beaumont MA (2002). FDIST2. Available from http://rubic rdg.ac.uk/ mab/software.html.

Bekkevold D, André C, Dahlgren TG, Clausen LAW, Torstensen $\mathrm{E}$, Mosegaard $\mathrm{H}$ et al. (2005). Environmental correlates of population differentiation in Atlantic herring. Evolution 59: 2656-2668.

Chevolot M, Ellis JR, Rijnsdorp AD, Stam WT, Olsen JL (2008). Temporal changes in allele frequencies but stable genetic diversity over the past 40 years in the Irish Sea population of thornback ray, Raja clavata. Heredity 101: 120-126.

Conover DO, Munch SB (2002). Sustaining fisheries yields over evolutionary time scales. Science 297: 94-96.

Cornuet JM, Luikart G (1996). Description and power analysis of two tests for detecting recent population bottlenecks from allele frequency data. Genetics 144: 2001-2014.

Crow JF, Kimura M (1970). An Introduction to Population Genetics Theory. Harper and Row: New York, NY, 591 pp.

Dannewitz J, Maes GE, Johansson L, Wickström H, Volckaert FAM, Järvi T (2005). Panmixia in the European eel: a matter of time... Proc R Soc B 272: 1129-1137.

Frankham R (1995). Effective population size/adult population size ratios in wildlife: a review. Genet Res 66: 95-107.

Goudet J (1995). FSTAT (Version 1.2): a computer program to calculate F-statistics. J Hered 86: 485-486.

Goudet J (2001). FSTAT, a program to estimate and test gene diversities and fixation indices (version 2.9.3). Available from http://www.unil.ch/izea/softwares/fstat.html.

Grant WS, Bowen BW (1998). Shallow population histories in deep evolutionary lineages of marine fishes: insights from sardines and anchovies and lessons for conservation. I Hered 89: 415-426.

Harrison S, Taylor AD (1997). Empirical evidence for metapopulation dynamics. In: Hanski I, Gilpin ME (eds). Metapopulation Biology: Ecology, Genetics, and Evolution. Academic Press: London, pp 27-39.

Hastings A (1993). Complex interactions between dispersal and dynamics: lessons from coupled logistic equations. Ecology 74: $1362-1372$. 
Hauser L, Adcock GJ, Smith PJ, Bernal Ramirez JH, Carvalho GR (2002). Loss of microsatellite diversity and low effective population size in an overexploited population of New Zealand snapper (Pagrus auratus). PNAS 99: 11742-11747.

Hauser L, Carvalho GR (2008). Paradigm shifts in marine fisheries genetics: ugly hypotheses slain by beautiful facts. Fish Fisheries 9: 333-362.

Hedgecock D (1994). Does variance in reproductive success limit effective population size of marine organisms?. In: Beaumont, A (ed). Genetics and Evolution of Aquatic Organisms. Chapman and Hall: London, pp 122-134.

Hutchinson WF, van Oosterhout C, Rogers SI, Carvalho GR (2003). Temporal analysis of archived samples indicates marked genetic changes in declining North Sea cod (Gadus morhua). Proc R Soc B 270: 2125-2132.

Johannesson K, Tatarenkov A (1997). Allozyme variation in a snail (Littorina saxatilis)-deconfounding the effects of microhabitat and gene flow. Evolution 51: 402-409.

Jorde PE, Ryman N (1995). Temporal allele frequency change and estimation of effective size in populations with overlapping generations. Genetics 139: 1077-1090.

Jorde PE, Ryman N (2007). Unbiased estimator for genetic drift and effective population size. Genetics 177: 927-935.

Jørgensen $\mathrm{HBH}$, Hansen MM, Bekkevold D, Ruzzante DE, Loeschcke V (2005). Marine landscapes and population genetic structure of herring (Clupea harengus L.) in the Baltic Sea. Mol Ecol 14: 3219-3234.

Jørgensen $\mathrm{HBH}$, Pertoldi C, Hansen MM, Ruzzante DE, Loeschcke V (2008). Genetic and environmental correlates of morphological variation in a marine fish: the case of Baltic Sea herring (Clupea harengus). Can J Fish Aquat Sci 65: 389-400.

Laikre L, Ryman N (1996). Effects on intraspecific biodiversity from harvesting and enhancing natural populations. Ambio 25: 504-509.

Laikre L, Larsson LC, Palmé A, Charlier J, Josefsson M, Ryman N (2008). Potentials for monitoring gene level biodiversity: using Sweden as an example. Biodivers Conserv 17: 893-910.

Larsson LC, Laikre L, Palm S, André C, Carvalho GR, Ryman N (2007). Concordance of allozyme and microsatellite differentiation in a marine fish, but evidence of selection at a microsatellite locus. Mol Ecol 16: 1135-1147.

Laurent V, Planes S (2007). Effective population size estimation on Sardina pilchardus in the Bay of Biscay using a temporal genetic approach. Biol J Linnean Soc 90: 591-602.

Lewis PO, Zaykin D (2001). Genetic Data Analysis: computer program for the analysis if allelic data. Version 1.0 (d16c). Free program distributed over the internet from http:// lewis.eeb.uconn.edu/lewishome/software.html.

Luikart G, Cournet J-M, Allendorf FW (1999). Temporal changes in allele frequencies provide estimates of population bottleneck size. Conserv Biol 13: 523-530.

MacKenzie BR, Alheit J, Conley DJ, Holm P, Kinze CC (2002). Ecological hypotheses for a historical reconstruction of upper trophic level biomass in the Baltic Sea and Skagerrak. Can J Fish Aquat Sci 59: 173-190.

Mariani S, Hutchinson WF, Hatfield EMC, Ruzzante DE, Simmonds EJ, Dahlgren TG et al. (2005). North Sea herring population structure revealed by microsatellite analysis. Mar Ecol Prog Ser 303: 245-257.

McPherson AA, O'Reilly PT, McParland TL, Jones MW, Bentzen $P$ (2001). Isolation of nine novel tetranucleotide microsatellites in Atlantic herring (Clupea harengus). Mol Ecol Notes 1: 31-32.

McPherson AA, O'Reilly PT, Taggart CT (2004). Genetic differentiation, temporal stability, and the absence of isolation by distance among Atlantic herring populations. Trans Am Fish Soc 133: 434-446.

McQuinn IH (1997). Metapopulations and the Atlantic herring. Rev Fish Biol Fish 7: 297-329.
Nei M, Tajima F (1981). Genetic drift and estimation of effective population size. Genetics 98: 625-640.

Olsen JB, Lewis CJ, Kretschmer EJ, Wilson SL, Seeb JE (2002). Characterization of 14 tetranucleotide microsatellite loci derived from Pacific herring. Mol Ecol Notes 2: 101-103.

Ovenden IR, Peel D, Street R, Courtney AJ, Hoyle SD, Peel SL et al. (2007). The genetic effective and adult census size of an Australian population of tiger prawns (Penaeus esculentus). Mol Ecol 16: 127-138.

Palsbøll PJ, Bérubé M, Allendorf FW (2007). Identification of management units using population genetic data. Trends Ecol Evol 22: 11-16.

Palstra FP, Ruzzante DE (2008). Genetic estimates of contemporary effective population size: what can they tell us about the importance of genetic stochasticity for wild population persistence? Mol Ecol 17: 3428-3447.

Piry S, Luikart G, Cornuet JM (1999). BOTTLENECK: a computer program for detecting recent reductions in the effective size using allele frequency data. J Hered 90: 502-503.

Poulsen NA, Nielsen EE, Shierup MH, Loeschcke V, Grønkjær P (2006). Long-term stability and effective population size in North Sea and Baltic Sea cod (Gadus morhua). Mol Ecol 15: 321-331.

Raymond M, Rousset F (1995). GENEPOP (Version 1.2): population genetics software for exact tests and ecumenicism. J Hered 86: 248-249.

Ruzzante DE, Taggart CT, Doyle RW, Cook D (2001). Stability in the historical pattern of genetic structure of Newfoundland cod (Gadus morhua) despite the catastrophic decline in population size from 1964 to 1994 . Cons Gen 2: 257-269.

Ruzzante DE, Mariani S, Bekkevold D, André C, Mosegaard H, Clausen LAW et al. (2006). Biocomplexity in a highly migratory pelagic marine fish, Atlantic herring. Proc $R$ Soc $B$ 273: $1459-1464$.

Ryman N (2006). CHIFISH: a computer program testing for genetic heterogeneity at multiple loci using chi-square and Fisher's exact test. Mol Ecol Notes 6: 285-287.

Ryman N, Baccus R, Reuterwall C, Smith MH (1981). Effective population size, generation interval, and potential loss of genetic variability in game species under different hunting regimes. Oikos 36: 257-266.

Ryman N, Lagercrantz U, Andersson L, Chakraborty R, Rosenberg R (1984). Lack of correspondence between genetic and morphologic variability patterns in Atlantic herring. Heredity 53: 687-704.

Ryman N, Utter F, Laikre L (1995). Protection of intraspecific biodiversity of exploited fishes. Rev Fish Biol Fish 5: 417-446.

Ryman N, Palm S, André C, Carvalho GR, Dahlgren TG, Jorde PE et al. (2006). Power for detecting genetic divergence: differences between statistical methods and marker loci. Mol Ecol 15: 2031-2045.

Shaklee JB, Allendorf FW, Morizot DC, Whitt GS (1990). Gene nomenclature for protein-coding loci in fish. Trans Am Fish Soc 119: 2-15.

Skalski GT (2007). Joint estimation of migration rate and effective population size using the island model. Genetics 177: 1043-1057.

Small MP, Loxterman JL, Frye AE, Von Bargen JF, Bowman C, Young SF (2005). Temporal and spatial genetic structure among some Pacific herring populations in Puget Sound and the southern Strait of Georgia. Trans Am Fish Soc 134: 1329-1341.

Smith PJ, Francis RICC, McVeagh M (1991). Loss of genetic diversity due to fishing pressure. Fish Res 10: 309-316.

van Oosterhout C, Hutchinson WF, Wills DPM, Shipley P (2004). MICRO-CHECKER: software for identifying and correcting genotyping errors in microsatellite data. Mol Ecol Notes 4: 535-538.

Wang J (2001). A pseudo-likelihood method for estimating effective population size from temporally spaced samples. Genet Res 78: 243-257. 
Wang J, Whitlock MC (2003). Estimating effective population size and migration rates from genetic samples over time and space. Genetics 163: 429-446.

Waples RS (1989). Temporal variation in allele frequencies: testing the right hypothesis. Evolution 43: 1236-1251.

Waples RS (2006). A bias correction for estimates of effective population size based on linkage disequilibrium at unlinked gene loci. Conserv Genet 7: 167-184.
Waples RS, Yokota M (2007). Temporal estimates of effective population size in species with overlapping generations. Genetics 175: 219-233.

Waples RS, Do C (2008). LDNE: a program for estimating effective population size from data on linkage disequilibrium. Mol Ecol Res 8: 753-756.

Weir BS, Cockerham CC (1984). Estimating F-statistics for the analysis of population structure. Evolution 38: 1358-1370.

\section{Appendix 1}

Descriptive statistics and pairwise comparisons for 11 allozyme and eight microsatellite presumed neutral loci of the cohorts in temporally separated samples of Atlantic herring from five locations

\begin{tabular}{|c|c|c|c|c|c|c|c|c|c|c|c|c|c|c|c|c|c|}
\hline \multirow[t]{2}{*}{ Locality } & \multirow[t]{2}{*}{ Cohort } & \multirow[t]{2}{*}{$\mathrm{n}$} & \multirow[t]{2}{*}{$\mathrm{H}_{E}$} & \multirow[t]{2}{*}{$\mathrm{H}_{O}$} & \multirow[t]{2}{*}{$\mathrm{AR}$} & \multicolumn{12}{|c|}{ Pairwise $\mathrm{F}_{S T}$ between cohorts below diagonal, nominal P-values above } \\
\hline & & & & & & 1974 & 1975 & 1976 & 1977 & 1993 & 1994 & 1995 & 1996 & 1997 & 1998 & 1999 & 2000 \\
\hline \multicolumn{18}{|c|}{ Flatbrotten } \\
\hline & 1974 & $20(18)$ & 0.445 & 0.440 & 4.83 & - & 0.004 & 0.045 & - & - & - & - & - & - & 0.058 & 0.059 & 0.125 \\
\hline & 1975 & $24(23)$ & 0.447 & $0.408^{* * *}$ & 4.77 & 0.004 & - & 0.009 & - & - & - & - & - & - & 0.280 & 0.013 & 0.034 \\
\hline & 1976 & $43(42)$ & 0.444 & 0.436 & 4.91 & 0.006 & 0.004 & - & - & - & - & - & - & - & 0.027 & 0.088 & 0.094 \\
\hline & 1998 & $106(96)$ & 0.445 & 0.436 & 4.86 & 0.002 & -0.002 & 0.002 & - & - & - & - & - & - & - & 0.043 & 0.009 \\
\hline & 1999 & $56(52)$ & 0.448 & 0.437 & 4.91 & 0.004 & 0.003 & 0.002 & - & - & - & - & - & - & 0.001 & - & 0.006 \\
\hline & 2000 & $48(42)$ & 0.457 & 0.450 & 4.89 & 0.009 & 0.003 & 0.004 & - & - & - & - & - & - & 0.005 & 0.003 & - \\
\hline Måseskär & 1974 & $25(2$ & 0.4 & 0.4 & 4.98 & - & 0.0 & 0.594 & - & - & - & - & - & - & 0.313 & 0.869 & 0.454 \\
\hline & 1975 & $54(54)$ & 0.452 & $0.436^{*}$ & 4.88 & 0.000 & - & 0.310 & - & - & - & - & - & - & 0.001 & 0.011 & 0.002 \\
\hline & 1976 & $21(21)$ & 0.430 & 0.421 & 4.68 & -0.001 & -0.002 & - & - & - & - & - & - & - & 0.006 & 0.083 & 0.147 \\
\hline & 1998 & 115 (110) & 0.451 & 0.440 & 4.92 & -0.001 & 0.002 & 0.005 & - & - & - & - & - & - & - & 0.411 & 0.392 \\
\hline & 1999 & $52(47)$ & 0.443 & $0.426^{*}$ & 4.86 & -0.002 & 0.002 & 0.003 & - & - & - & - & - & - & -0.001 & - & 0.664 \\
\hline & 2000 & $36(27)$ & 0.434 & 0.426 & 4.92 & -0.002 & 0.003 & 0.000 & - & - & - & - & - & - & 0.000 & -0.003 & - \\
\hline \multicolumn{18}{|c|}{ Himmerfjärden } \\
\hline & 1993 & $24(12)$ & 0.447 & 0.445 & 4.91 & - & - & - & - & - & 0.868 & 0.295 & 0.849 & 0.382 & 0.879 & 0.529 & 0.409 \\
\hline & 1994 & $39(20)$ & 0.443 & 0.445 & 4.94 & - & - & - & - & -0.006 & - & 0.533 & 0.908 & 0.335 & 0.575 & 0.427 & 0.133 \\
\hline & 1995 & $45(18)$ & 0.422 & 0.434 & 4.60 & - & - & - & - & 0.001 & -0.003 & - & 0.589 & 0.000 & 0.151 & 0.088 & 0.179 \\
\hline & 1996 & $56(20)$ & 0.445 & 0.441 & 4.75 & - & - & - & - & -0.003 & -0.001 & 0.005 & - & 0.252 & 0.448 & 0.041 & 0.462 \\
\hline & 1997 & $40(8)$ & 0.418 & 0.411 & $\mathrm{NA}^{\mathrm{a}}$ & - & - & - & - & 0.008 & 0.005 & 0.017 & 0.008 & - & 0.031 & 0.061 & 0.195 \\
\hline & 1998 & $57(10)$ & 0.444 & 0.455 & $\mathrm{NA}^{\mathrm{a}}$ & - & - & - & - & -0.004 & -0.005 & 0.004 & 0.003 & 0.010 & - & 0.444 & 0.303 \\
\hline & 1999 & $34(0)$ & 0.144 & 0.134 & $\mathrm{NA}^{\mathrm{a}}$ & - & - & - & - & 0.004 & 0.012 & 0.015 & 0.018 & 0.012 & 0.006 & - & 0.049 \\
\hline & 2000 & $55(2)$ & 0.458 & 0.471 & $\mathrm{NA}^{\mathrm{a}}$ & - & - & - & - & 0.002 & 0.002 & 0.004 & -0.002 & 0.005 & 0.003 & 0.010 & - \\
\hline $0.002-0.002-0.004-0.002-0.000 \quad 0.000$ & 1997 & $30(25)$ & 0.442 & 0.434 & 4.63 & - & - & - & - & - & - & - & - & - & 0.065 & 0234 & - \\
\hline & 1998 & $76(62)$ & 0.442 & $0.426^{* *}$ & 4.90 & - & - & - & - & - & - & - & - & 0.003 & - & 0.429 & - \\
\hline & 1999 & 78 (73) & 0.434 & $0.421^{*}$ & 4.84 & - & - & - & - & - & - & - & - & 0.000 & -0.001 & - & - \\
\hline vaxnom & 1975 & $22(22)$ & 0.442 & 0.442 & 4.69 & - & - & 0.032 & 0.171 & - & - & - & - & 0.065 & 0.004 & 0.001 & - \\
\hline & 1976 & $33(33)$ & 0.436 & 0.450 & 4.91 & - & -0.002 & - & 0.151 & - & - & - & - & 0.092 & 0.066 & 0.204 & - \\
\hline & 1977 & $23(22)$ & 0.431 & 0.427 & 4.85 & - & 0.008 & 0.000 & - & - & - & - & - & 0.001 & 0.002 & 0.086 & - \\
\hline & 1997 & $36(26)$ & 0.430 & 0.418 & 4.74 & - & 0.009 & 0.008 & 0.015 & - & - & - & - & - & 0.305 & 0.461 & - \\
\hline & 1998 & 62 (29) & 0.431 & 0.432 & 4.87 & - & 0.003 & 0.003 & 0.007 & - & - & - & - & 0.004 & - & 0.573 & - \\
\hline & 1999 & 71 (19) & 0.434 & $0.417^{*}$ & 4.70 & - & 0.004 & -0.001 & 0.000 & - & - & - & - & 0.002 & -0.002 & - & - \\
\hline
\end{tabular}

Abbreviations: $A R$, allelic richness based on minimum sample size of $12 ; n$, sample size (no. of individuals scored for microsatellites in parenthesis); $H_{\mathrm{E}}$, expected heterozygosity; $H_{\mathrm{O}}$, observed heterozygosity; departure from Hardy-Weinberg equilibrium noted with ${ }^{*} P<0.05$; $* * P<0.01 ; * * * P<0.001$.

Significant pairwise differentiation between cohorts from the same locality are marked in bold. Bonferroni corrections have not been applied. ${ }^{a}$ Not available, not included in allelic richness calculations since no or very few microsatellites were genotyped. 